\title{
Insight into Platinum Poisoning Effect on Cu-SSZ-13 in Selective Catalytic Reduction of $\mathrm{NO}_{x}$ with $\mathrm{NH}_{3}$
}

\author{
Huawang Zhao ${ }^{1, *}$, Lei Han ${ }^{2}$, Yujie Wang ${ }^{3}$ and Jiandong Zheng ${ }^{3}$ \\ 1 Department of Environmental Science \& Engineering, College of Chemical Engineering, Huaqiao University, \\ Xiamen 361021, China \\ 2 School of Chemical Engineering, Tianjin University, Tianjin 300072, China; leihan@tju.edu.cn \\ 3 School of Materials and Chemical Engineering, Chuzhou University, Chuzhou 239000, China; \\ 15243229372@163.com (Y.W.); zjd07@126.com (J.Z.) \\ * Correspondence: hwzhao@hqu.edu.cn
}

check for updates

Citation: Zhao, H.; Han, L.; Wang, Y.;

Zheng, J. Insight into Platinum

Poisoning Effect on Cu-SSZ-13 in Selective Catalytic Reduction of $\mathrm{NO}_{\mathrm{x}}$ with $\mathrm{NH}_{3}$. Catalysts 2021, 11, 796. https://doi.org/10.3390/

catal11070796

Academic Editor: Young-Kwon Park

Received: 13 May 2021

Accepted: 28 June 2021

Published: 29 June 2021

Publisher's Note: MDPI stays neutral with regard to jurisdictional claims in published maps and institutional affiliations.

Copyright: (c) 2021 by the authors. Licensee MDPI, Basel, Switzerland. This article is an open access article distributed under the terms and conditions of the Creative Commons Attribution (CC BY) license (https:// creativecommons.org/licenses/by/ $4.0 /)$.

\begin{abstract}
Platinum's (Pt) poisoning effect on Cu-SSZ-13 and its regeneration were investigated. The Pt enhanced the parallel reactions, such as $\mathrm{NH}_{3}$ oxidation and NO oxidation reactions, which decreased the deNOx activities. In the temperature range below $330^{\circ} \mathrm{C}$, the deactivation of $\mathrm{Cu}-\mathrm{SSZ}$ 13 by $\mathrm{Pt}$ poisoning was primarily caused by the overconsumption of $\mathrm{NH}_{3}$, due to the enhanced $\mathrm{NH}_{3}$-selective oxidation reaction, while the formation of $\mathrm{NO}_{\mathrm{x}}$ in $\mathrm{NH}_{3}$ oxidation and $\mathrm{NO}$ oxidation into $\mathrm{NO}_{2}$ further aggravated the degradation when the temperature was above $460{ }^{\circ} \mathrm{C}$. The nonselective $\mathrm{NH}_{3}$ oxidation and non-selective $\mathrm{NO}_{x}$ catalytic reduction reactions resulted in increased $\mathrm{N}_{2} \mathrm{O}$ formation over Pt-doped samples. The transformation of $\mathrm{Pt}^{0}$ into $\mathrm{PtO}_{\mathrm{x}}$ after hydrothermal aging recovered the deNO $\mathrm{N}_{\mathrm{x}}$ activities of the Pt-poisoned samples.
\end{abstract}

Keywords: Pt poisoning; Cu-SSZ-13; $\mathrm{NH}_{3}-\mathrm{SCR}$; regeneration

\section{Introduction}

$\mathrm{Cu}$-exchanged SSZ-13 has recently been commercialized as a catalyst for the selective catalytic reduction of $\mathrm{NO}_{x}$ with a $\mathrm{NH}_{3}\left(\mathrm{NH}_{3}-\mathrm{SCR}\right)$ section in a diesel engine exhaust aftertreatment system [1]. For automotive applications, there is a critical requirement for the application life of the SCR catalyst in order to meet the NOx emission standard [2].

Sulfur poisoning (including $\mathrm{SO}_{2}$ and $\mathrm{SO}_{3}$ ), hydrothermal aging, and chemical contamination (such as $\mathrm{Ca}, \mathrm{P}, \mathrm{Pt}, \mathrm{Pd}$, etc.) would deactivate the Cu-SSZ-13 [3-7]. Specific to the sulfur poisoning, the deactivation caused by $\mathrm{SO}_{2}$ poisoning is mostly reversible, as $\mathrm{NH}_{4} \mathrm{HSO}_{4}$ and $\mathrm{CuHSO}_{4}$ intermediates formed on Cu-SSZ-13 can be decomposed after thermal treatment at high temperatures [8]. However, the deactivation caused by $\mathrm{SO}_{3}$ poisoning due to the formation of copper sulfate and structural damage is irreversible [3,7].

Specific to hydrothermal treatment, the deactivation of Cu-SSZ-13 is typically attributed to the destruction and transformation of cupric sites from SCR-active to -inactive forms, which is irreversible [5,9]. Nevertheless, the effect of chemical poisoning on Cu-SSZ13 is more complex than that of sulfur poisoning and hydrothermal treatment. In addition to the poisoning effect of the destruction and transformation of isolated $\mathrm{Cu}^{2+}$ ions into inactive forms [6,10-12], the additional chemical contaminants may act as active sites that catalyze side reactions in the $\mathrm{NH}_{3}-\mathrm{SCR}$ reaction system.

In general, the standard SCR reaction is the target pathway for the $\mathrm{NO}_{\mathrm{x}}$ elimination in the $\mathrm{NH}_{3}$-SCR system, as shown in Reaction 1 (R.1):

$$
4 \mathrm{NH}_{3}+4 \mathrm{NO}+\mathrm{O}_{2}=4 \mathrm{~N}_{2}+6 \mathrm{H}_{2}
$$

However, some parallel reactions also occur along with the standard reaction, as shown in R.2-R.7.

$$
4 \mathrm{NO}+4 \mathrm{NH}_{3}+3 \mathrm{O}_{2}=4 \mathrm{~N}_{2} \mathrm{O}+6 \mathrm{H}_{2} \mathrm{O}
$$




$$
\begin{gathered}
4 \mathrm{NH}_{3}+3 \mathrm{O}_{2}=2 \mathrm{~N}_{2}+6 \mathrm{H}_{2} \mathrm{O} \\
2 \mathrm{NH}_{3}+2 \mathrm{O}_{2}=\mathrm{N}_{2} \mathrm{O}+3 \mathrm{H}_{2} \mathrm{O} \\
4 \mathrm{NH}_{3}+5 \mathrm{O}_{2}=4 \mathrm{NO}+6 \mathrm{H}_{2} \mathrm{O} \\
4 \mathrm{NH}_{3}+7 \mathrm{O}_{2}=4 \mathrm{NO}_{2}+6 \mathrm{H}_{2} \mathrm{O} \\
2 \mathrm{NO}+\mathrm{O}_{2}=2 \mathrm{NO}_{2}
\end{gathered}
$$

Without the contaminants, the rate of the standard $\mathrm{NH}_{3}-\mathrm{SCR}$ reaction is much higher than that of the side reactions when using the Cu-SSZ-13 as catalyst, because the isolated $\mathrm{Cu}^{2+}$ ions primarily catalyze the standard reaction $[13,14]$. Therefore, the Cu-SSZ-13 exhibited excellent deNOx activity. However, the presence of additional chemical contamination sites might help to catalyze the reactions in R.2-R.7, which increases the parallel reactions rate [6]. As such, the competition between the parallel reactions (R.2-R.7) and the standard reaction (R.1) would reduce the SCR activity of Cu-SSZ-13 (R.1) [6].

$\mathrm{Pt}$ is a typical chemical contamination species for $\mathrm{Cu}$-SSZ-13 [6]. In an after-treatment system, the SCR catalyst is located downstream of the diesel oxidation catalyst (DOC) and diesel particulate filter (DPF) sections [15]. The Pt coating in DOC and DPF would be volatilized and deposited on the SCR catalyst due to the high exhaust temperature, which significantly decreases the deNOx activities of the SCR catalysts [16-18]. The previous work in the industry investigated the Pt poisoning effect on Cu-SSZ-13 with Pt loading in the weight range of $0-0.016 \mathrm{wt}$. \% [19]. This work found that $0.008 \mathrm{wt}$. \% was the threshold with little influence on the activity of Cu-SSZ-13, above which the activity decreased significantly. Lezcano-Gonzalez et al. [6] investigated the effect of series pollutants ( $\mathrm{Pt}, \mathrm{Zn}$, $\mathrm{Ca}$ and $\mathrm{P}$ ) on $\mathrm{Cu} / \mathrm{SSZ}-13$ catalysts during the $\mathrm{NH}_{3}$-SCR process, and $\mathrm{Pt}$ poisoning (with Pt loading of 1-2 wt. \%) resulted in the NOx conversion reduction, which was predicted to be due to the Pt species' oxidation ability that promoted the $\mathrm{NH}_{3}$ oxidation reaction (R.3-R.6). A similar poisoning effect of Pt was also observed on Cu-SAPO-34 [18]. It should be noted that the amount of Pt has a significant impact on the SCR performance of Cu-SSZ-13 [19]. Therefore, the effect of a Pt loading of 0.01-0.1 wt. \% on Cu-SSZ-13 should be investigated. In addition, the hydrothermal treatment effect on the Pt poisoning influence on Pt/Cu-SSZ-13 has also not been reported.

In this work, a series of $\mathrm{Pt} / \mathrm{Cu}-\mathrm{SSZ}-13$ samples with different $\mathrm{Pt}$ doping contents (0.01-0.1 wt. \%) was prepared to elucidate the poisoning impact of Pt on the $\mathrm{NH}_{3}-\mathrm{SCR}$ performance of the catalysts. The $\mathrm{Pt}^{\prime} \mathrm{s}$ influence on the $\mathrm{NH}_{3}-\mathrm{SCR}$ reaction network was investigated based on transient reaction experiments. The Pt poisoning effects on the structure and cupric sites of Cu-SSZ-13 were evaluated by XRD and $\mathrm{H}_{2}$-TPR measurements. The effect of hydrothermal treatment on the recovery of a Pt-contaminated sample was analyzed.

\section{Results and Discussion}

\subsection{Influence of Pt Poisoning on the Catalytic Performance of Cu-SSZ-13}

Figure 1 shows the SCR performance of the Cu-SSZ-13 and Pt poisoning samples with and without hydrothermal treatment. The Cu-SSZ-13 presented above $75 \%$ NOx conversion at $150-550{ }^{\circ} \mathrm{C}$, and the $\mathrm{N}_{2} \mathrm{O}$ concentration was below $20 \mathrm{ppm}$, indicating that the $\mathrm{NO}$ and $\mathrm{NH}_{3}$ were primarily converted via the standard $\mathrm{NH}_{3}-\mathrm{SCR}$ reaction (R.1) pathway over Cu-SSZ-13. For Cu-SSZ-13 doping with $\mathrm{Pt}(\mathrm{PtxCu})$, the NOx conversion decreased with increasing $\mathrm{Pt}$ loading, particularly in the temperature range above $300^{\circ} \mathrm{C}$. Notably, larger concentrations of $\mathrm{N}_{2} \mathrm{O}$ were formed in PtxCu samples than in Cu-SSZ-13 (Figure 2). This indicates that the parallel reactions (e.g., R.2-R.7) should be accelerated by $\mathrm{Pt}$ sites $[18,20]$. In addition, the $\mathrm{N}_{2} \mathrm{O}$ formation shows a volcanic curve, with the peaks at around $330{ }^{\circ} \mathrm{C}$ in the $\mathrm{Pt}$-doped samples. This demonstrates that the parallel reactions (such as R.2 and R.4) contributing to the $\mathrm{N}_{2} \mathrm{O}$ formation mainly affect the $\mathrm{NO}_{\mathrm{x}}$ conversion below $330^{\circ} \mathrm{C}$. In other words, some other parallel reactions resulted in a decrease in deNO activity above $330^{\circ} \mathrm{C}$. This part will be further analyzed in Section 3.2, accompanied by 
the transient reaction results. In addition, in our work, the $\mathrm{NO}_{\mathrm{x}}$ conversion decreased with the increasing Pt loading from 0.01 to $0.1 \mathrm{wt}$ \% (Figure 1). However, in the work by Lezcano-Gonzalez et al. [6], the Pt-poisoned Cu-SSZ-13 showed a similar loss of NOx conversion in the Cu-SSZ-13 with Pt loadings of 1 and $2 \mathrm{wt}$. \%. This indicates that the Pt poisoning effect might not change significantly when the $\mathrm{Pt}$ loading reaches a high content (around $1 \mathrm{wt} . \%$ ).

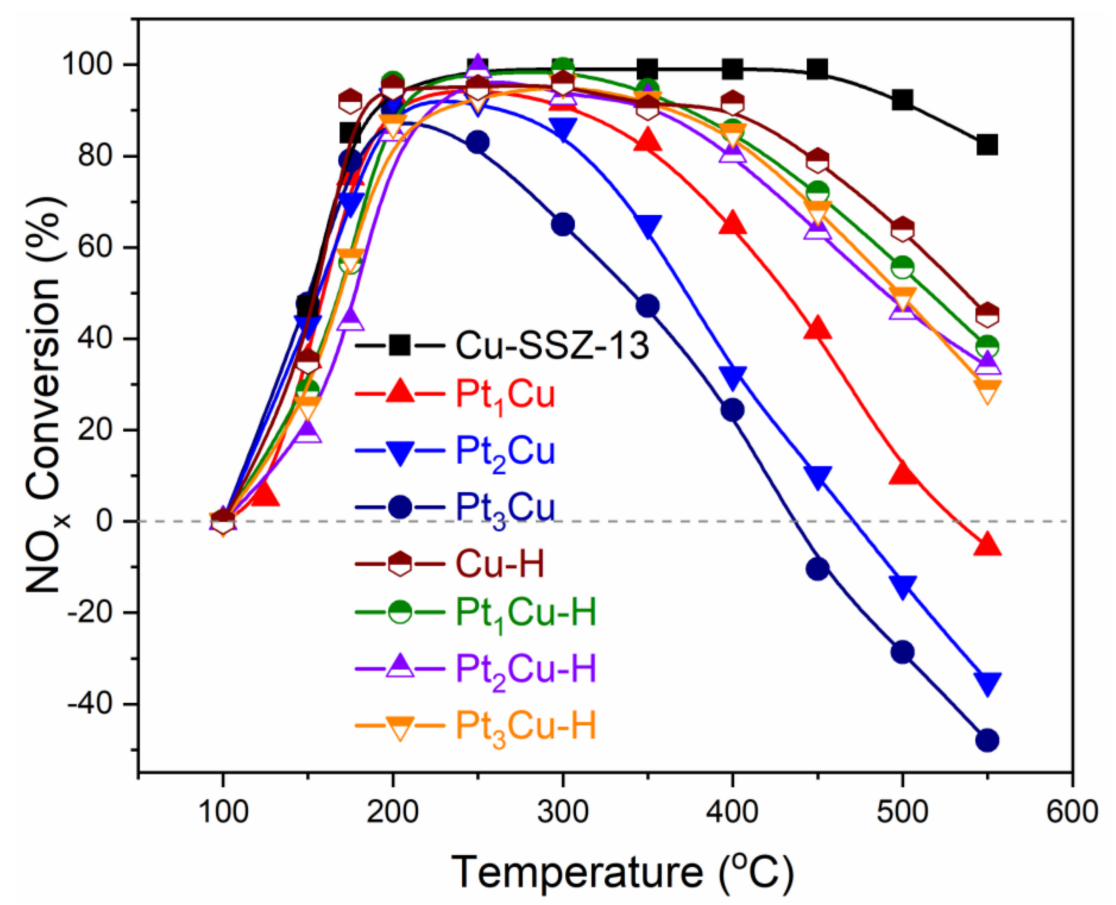

Figure 1. $\mathrm{NO}_{\mathrm{x}}$ conversion during standard $\mathrm{NH}_{3}-\mathrm{SCR}$ with the fresh and aged samples. The reaction conditions: $500 \mathrm{ppm} \mathrm{NH}_{3}, 500 \mathrm{ppm} \mathrm{NO}, 5 \% \mathrm{O}_{2}, 5 \% \mathrm{H}_{2} \mathrm{O}, \mathrm{N}_{2}$ balance, flow rate at $500 \mathrm{~mL} / \mathrm{min}$, $100 \mathrm{mg}$ of catalyst.

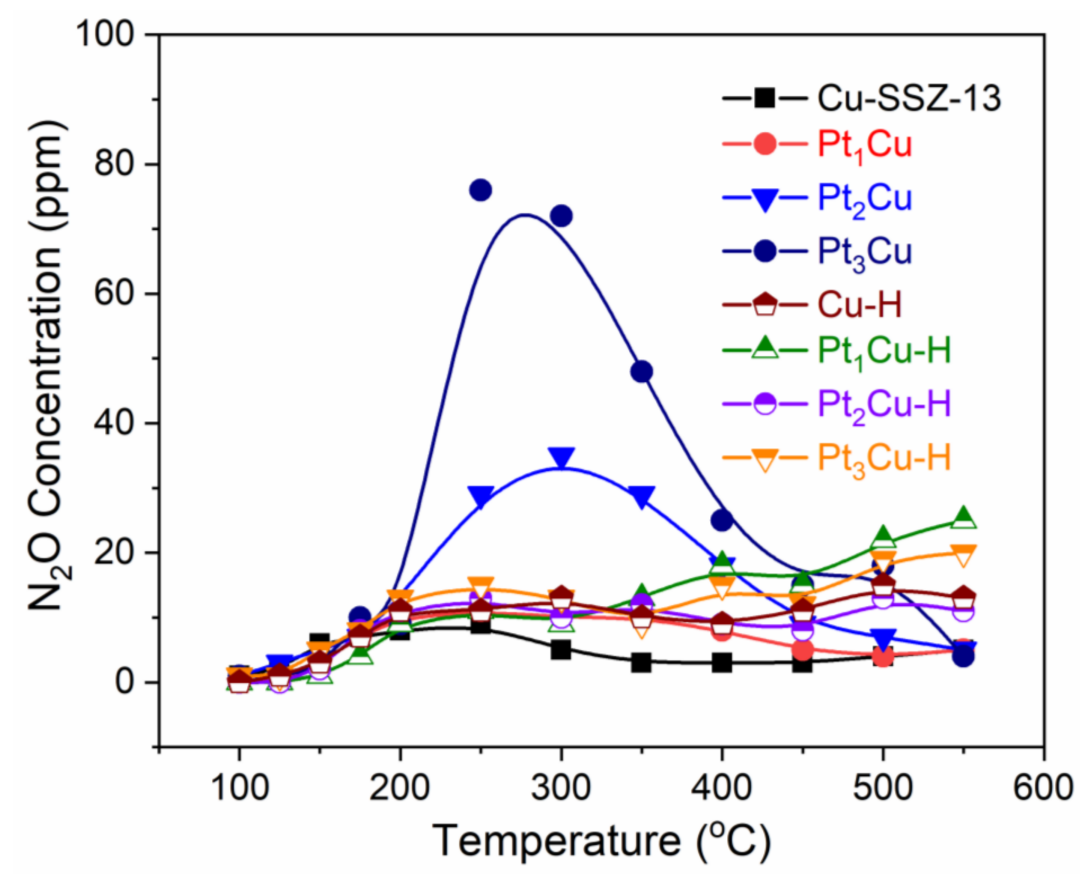

Figure 2. $\mathrm{N}_{2} \mathrm{O}$ concentration during standard $\mathrm{NH}_{3}-\mathrm{SCR}$ of fresh and aged catalyst samples. The reaction conditions: 500 ppm $\mathrm{NH}_{3}, 500 \mathrm{ppm} \mathrm{NO}, 5 \% \mathrm{O}_{2}, 5 \% \mathrm{H}_{2} \mathrm{O}, \mathrm{N}_{2}$ balance, flow rate at $500 \mathrm{~mL} / \mathrm{min}$, $100 \mathrm{mg}$ of catalyst. 
The $\mathrm{NO}_{x}$ conversion of $\mathrm{Cu}-\mathrm{SSZ}-13$ decreased after hydrothermal treatment. However, the hydrothermally aged $\mathrm{PtxCu}$ samples showed only slightly inferior $\mathrm{NO}_{\mathrm{x}}$ conversions as compared to the $\mathrm{Cu}-\mathrm{H}$ sample, which was much higher than its fresh counterparts, as shown in Figures 1 and 2. In addition, the $\mathrm{N}_{2} \mathrm{O}$ formation over the PtxCu samples decreased after hydrothermal treatment. This demonstrates that the hydrothermal treatment partially recovered the activity of Pt-poisoned Cu-SSZ-13.

\subsection{Transient Reactions}

To investigate the effect of $\mathrm{Pt}$ on the standard $\mathrm{NH}_{3}-\mathrm{SCR}$ reaction and parallel reactions with Cu-SSZ-13 below and above $330{ }^{\circ} \mathrm{C}$, the transient reactions were conducted, and the results are given in Table 1 . The procedure of the transient reactions is shown in Figure 3. The $\mathrm{NH}_{3}$ oxidation results in Figure S1 reveal that the Pt poisoning enhanced the $\mathrm{NH}_{3}$ oxidation capacity of PtxCu samples. However, small amounts of $\mathrm{NO}$ and $\mathrm{NO}_{2}$ were formed on the Cu-SSZ-13 and Pt-poisoned samples during the $\mathrm{NH}_{3}$ oxidation period at $330{ }^{\circ} \mathrm{C}$, as shown in Table 1 . This indicates that the Pt sites mainly enhanced the $\mathrm{NH}_{3}$ selectivity of the oxidation reaction to $\mathrm{N}_{2}$ (R.3), which led to insufficient $\mathrm{NH}_{3}$ taking part in the standard SCR reaction, and decreased the $\mathrm{NO}_{x}$ conversion of PtxCu samples (Figure 1) below $330{ }^{\circ} \mathrm{C}$ as a result.

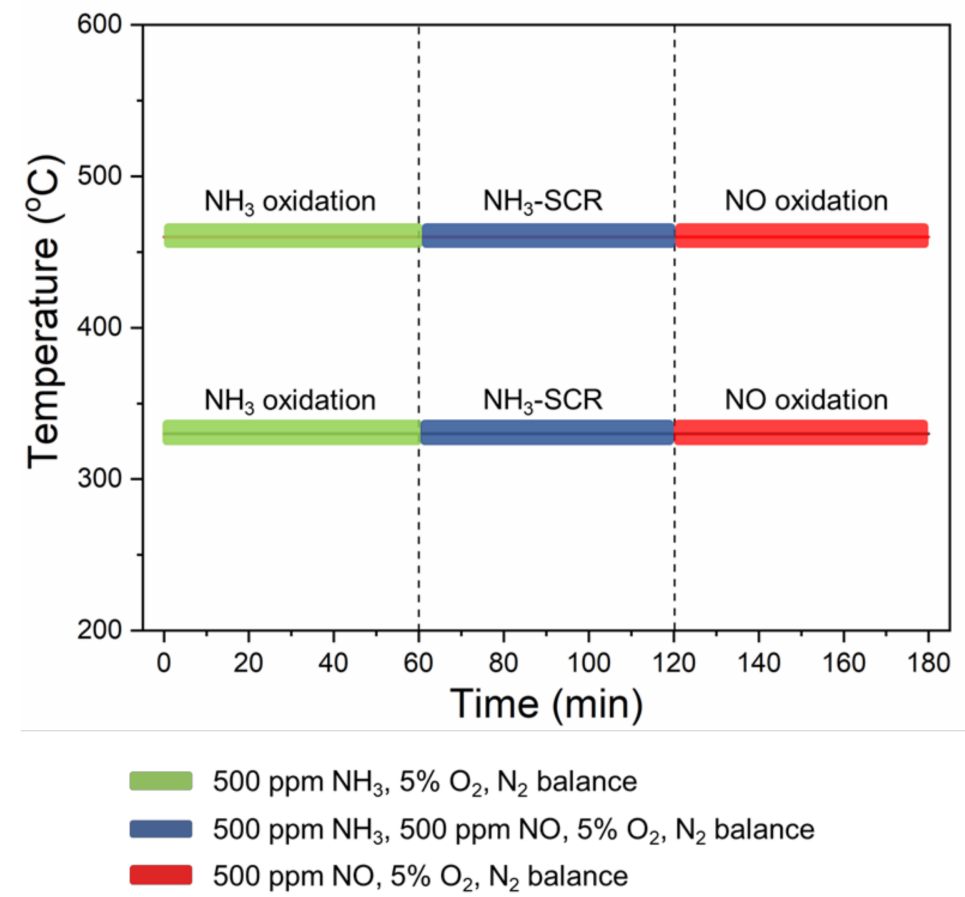

Figure 3. The procedure of the transient reactions.

Both the non-selective $\mathrm{NH}_{3}$ oxidation reaction (NSNO, R.4) and the non-selective $\mathrm{NO}_{x}$ catalytic reduction reaction (NSCR, R.2) contributed to the $\mathrm{N}_{2} \mathrm{O}$ formation [21]. The larger content of $\mathrm{N}_{2} \mathrm{O}$ in the PtxCu sample than Cu-SSZ-13 (Figure 2) must be attributed to the enhancement of the NSNO and NSCR reaction rates. However, the $\mathrm{N}_{2} \mathrm{O}$ formation cannot be attributed to the enhancement of the non-selective $\mathrm{NH}_{3}$ oxidation reaction (NSNO, R.4), because only a low concentration of $\mathrm{N}_{2} \mathrm{O}$ was formed in the $\mathrm{NH}_{3}$ oxidation period at $330{ }^{\circ} \mathrm{C}$, as shown in Table 1 . After the introduction of $\mathrm{NO}$, the $\mathrm{N}_{2} \mathrm{O}$ concentration was significantly increased (Table 1 ). This indicates that the $\mathrm{N}_{2} \mathrm{O}$ formation was primarily attributed to the non-selective $\mathrm{NO}_{x}$ catalytic reduction reaction (NSCR, R.2), which was catalyzed by Pt sites. 
Table 1. Transient reaction results for the catalyst samples at $330{ }^{\circ} \mathrm{C}$ and $460{ }^{\circ} \mathrm{C}$.

\begin{tabular}{|c|c|c|c|c|c|c|c|c|c|c|c|c|}
\hline \multirow{2}{*}{\multicolumn{2}{|c|}{ Sample T $\left({ }^{\circ} \mathrm{C}\right)$}} & \multicolumn{11}{|c|}{ Reaction } \\
\hline & & \multicolumn{4}{|c|}{$\mathrm{NH}_{3}$ Oxidation } & \multicolumn{3}{|c|}{ SCR Reaction } & \multicolumn{4}{|c|}{ NO Oxidation } \\
\hline & & NO & $\mathrm{NH}_{3}$ & $\mathrm{~N}_{2} \mathrm{O}$ & $\mathrm{NO}_{2}$ & NO & $\mathrm{NH}_{3}$ & $\mathrm{~N}_{2} \mathrm{O}$ & $\mathrm{NO}_{2}$ & NO & $\mathrm{N}_{2} \mathrm{O}$ & $\mathrm{NO}_{2}$ \\
\hline & & \multicolumn{4}{|c|}{ (ppm) } & \multicolumn{3}{|c|}{ (ppm) } & \multicolumn{4}{|c|}{ (ppm) } \\
\hline \multirow{2}{*}{ Cu-SSZ-13 } & 330 & 0 & 59 & 4 & 0 & 0 & 0 & 4 & 0 & 485 & 1 & 5 \\
\hline & 460 & 0 & 0 & 1 & 0 & 0 & 0 & 5 & 0 & 479 & 1 & 13 \\
\hline \multirow{2}{*}{$\mathrm{Pt}_{1} \mathrm{Cu}$} & 330 & 0 & 0 & 7 & 0 & 85 & 0 & 18 & 11 & 465 & 1 & 12 \\
\hline & 460 & 48 & 0 & 4 & 3 & 306 & 0 & 8 & 44 & 437 & 1 & 56 \\
\hline \multirow{2}{*}{$\mathrm{Pt}_{2} \mathrm{Cu}$} & 330 & 0 & 0 & 12 & 0 & 152 & 0 & 39 & 14 & 435 & 2 & 23 \\
\hline & 460 & 98 & 0 & 4 & 23 & 356 & 0 & 8 & 92 & 397 & 1 & 81 \\
\hline \multirow{2}{*}{$\mathrm{Pt}_{3} \mathrm{Cu}$} & 330 & 17 & 0 & 24 & 10 & 232 & 0 & 59 & 29 & 424 & 1 & 35 \\
\hline & 460 & 160 & 0 & 5 & 35 & 488 & 0 & 12 & 118 & 404 & 1 & 90 \\
\hline
\end{tabular}

More $\mathrm{NO}$ was formed during the $\mathrm{NH}_{3}$ oxidation at $460{ }^{\circ} \mathrm{C}\left(\mathrm{R}\right.$.6) than at $330^{\circ} \mathrm{C}$. This indicates that, in addition to the decrease in reductant involved in the standard SCR reaction due to the enhancement of the $\mathrm{NH}_{3}$ oxidation reaction by $\mathrm{Pt}$, the oxidation of $\mathrm{NH}_{3}$ to $\mathrm{NO}$ (R.6) also contributed to the decrease in $\mathrm{NO}_{x}$ conversion at high temperatures $\left(460^{\circ} \mathrm{C}\right)$.

Besides this, at $460{ }^{\circ} \mathrm{C}$, a large amount of $\mathrm{NO}_{2}$ was also produced during the $\mathrm{NH}_{3}$ oxidation of Pt doping samples, while none was observed in Cu-SSZ-13 (Table 1), indicating that a part of the $\mathrm{NH}_{3}$ was oxidized to $\mathrm{NO}_{2}$ by $\mathrm{Pt}$ at $460{ }^{\circ} \mathrm{C}$. Meanwhile, $\mathrm{NO}$ oxidation into $\mathrm{NO}_{2}$ (R.7) was also enhanced in the PtxCu samples, as confirmed by the higher concentration of $\mathrm{NO}_{2}$ formed over PtxCu than Cu-SSZ-13 during the $\mathrm{NO}$ oxidation period (Table 1). Furthermore, the total concentration of $\mathrm{NO}_{2}$ formed in the $\mathrm{NH}_{3}$ oxidation and $\mathrm{NO}$ oxidation reactions was similar to that formed in the $\mathrm{NH}_{3}$-SCR period. This demonstrates that Pt loading accelerated the reactions in R.6 and R.7, resulting in the increased $\mathrm{NO}_{2}$ formation in the $\mathrm{NH}_{3}$-SCR process. Those observations above imply that, beside the overconsumption of $\mathrm{NH}_{3}$ following R.1, the additional $\mathrm{NO}$ and $\mathrm{NO}_{2}$ production via $\mathrm{NH}_{3}$ and $\mathrm{NO}$ oxidation (R.5-R.7) also led to the decline in $\mathrm{NO}_{\mathrm{x}}$ conversion in the PtxCu samples at high temperatures (around $460^{\circ} \mathrm{C}$ ) [22,23].

\subsection{Pt Poisoning Effect on the Texture and Structure}

The ICP results of the samples are given in Table 2. The fresh and aged samples showed similar $\mathrm{Cu}$ loading contents, and the Pt amount increased with the increment in the Pt loading. The hydrothermal treatment did not change the Pt content.

Table 2. The element content and textural properties of the catalysts.

\begin{tabular}{|c|c|c|c|c|}
\hline Sample & $\begin{array}{l}\text { Cu Content }{ }^{a} \\
\text { (wt. \%) }\end{array}$ & $\begin{array}{c}\text { Pt Content }{ }^{a} \\
\text { wt. } \%\end{array}$ & $\begin{array}{c}\text { Surface Area } \\
\left(\mathrm{m}^{2} / \mathrm{g}\right)\end{array}$ & $\begin{array}{l}\text { Pore Volume } \\
\qquad\left(\mathrm{cm}^{3} / \mathrm{g}\right)\end{array}$ \\
\hline Cu-SSZ-13 & 4.11 & $\mathrm{ND}^{\mathrm{e}}$ & 498 & 0.21 \\
\hline $\mathrm{Pt}_{1} \mathrm{Cu}$ & 4.13 & 0.009 & 412 & 0.2 \\
\hline $\mathrm{Pt}_{2} \mathrm{Cu}$ & 4.08 & 0.051 & 390 & 0.19 \\
\hline $\mathrm{Pt}_{3} \mathrm{Cu}$ & 4.14 & 0.1 & 382 & 0.19 \\
\hline $\mathrm{Cu}-\mathrm{H}$ & 4.06 & ND & 406 & 0.17 \\
\hline $\mathrm{Pt}_{1} \mathrm{Cu}-\mathrm{H}$ & 4.10 & 0.01 & 355 & 0.17 \\
\hline $\mathrm{Pt}_{2} \mathrm{Cu}-\mathrm{H}$ & 4.10 & 0.048 & 342 & 0.16 \\
\hline $\mathrm{Pt}_{3} \mathrm{Cu}-\mathrm{H}$ & 4.09 & 0.1 & 335 & 0.15 \\
\hline
\end{tabular}

a Determined with ICP. ${ }^{\mathrm{b}}$ Determined with $\mathrm{N}_{2}$ physisorption. 
The surface area and pore volume decreased with the increasing Pt loading (Table 2). No significant framework dealumination took place as a result of Pt impregnation, as only a slight decline of the peak at $58 \mathrm{ppm}$, attributed to the tetrahedral $\mathrm{Al}$ species, was observed in the Pt-doped samples compared to Cu-SSZ-13 (Figure S4) [14,24]. In addition, no significant formation of octahedrally coordinated $\mathrm{Al}$ species (showing a resonance peak at $0 \mathrm{ppm}$ ) could be detected [14,24]. These observations above indicate that the dealumination should not be the primary reason for the decline in BET surface area. Actually, SSZ-13 possesses small windows of about $3.8 \AA$, so mass transfer limitations might be induced due to the deposition of impurities, even at low quantities. Moreover, taking into account the diameter of $\mathrm{Pt}^{0}$ and $\mathrm{PtO}_{\mathrm{x}}$ (around $1 \mathrm{~nm}$, shown in the TEM results in Figure S6), it is reasonable to assume that some of the Pt might be located in the zeolite micropores, causing a decrease in the micropore volume and the BET surface area. However, those values were largely maintained after hydrothermal treatment, suggesting that the structure of the hydrothermally aged sample remains intact, consistent with the XRD results in Figure S2.

\subsection{Pt Poisoning Effect on the Catalytic Active Sites}

\subsection{1. $\mathrm{H}_{2}$-TPR}

The isolated $\mathrm{Cu}^{2+}$ ions are identified as the active sites that catalyze the standard $\mathrm{NH}_{3}$-SCR reaction [25-27]. $\mathrm{H}_{2}$-TPR was carried out on the catalysts to detect the state of cupric species, and the results are shown in Figure 4a. For the fresh samples, two peaks in $220-380^{\circ} \mathrm{C}$ and in $600-750{ }^{\circ} \mathrm{C}$ were observed, representing the reduction of isolated $\mathrm{Cu}^{2+}$ to $\mathrm{Cu}^{+}$(R.8) and the reduction of $\mathrm{Cu}^{+}$to $\mathrm{Cu}^{0}$ (R.9), respectively $[28,29]$.

$$
\begin{aligned}
& \mathrm{Cu}^{2+}+\frac{1}{2} \mathrm{H}_{2}=\mathrm{Cu}^{+}+\mathrm{H}^{+} \\
& \mathrm{Cu}^{+}+\frac{1}{2} \mathrm{H}_{2}=\mathrm{Cu}^{0}+\mathrm{H}^{+}
\end{aligned}
$$
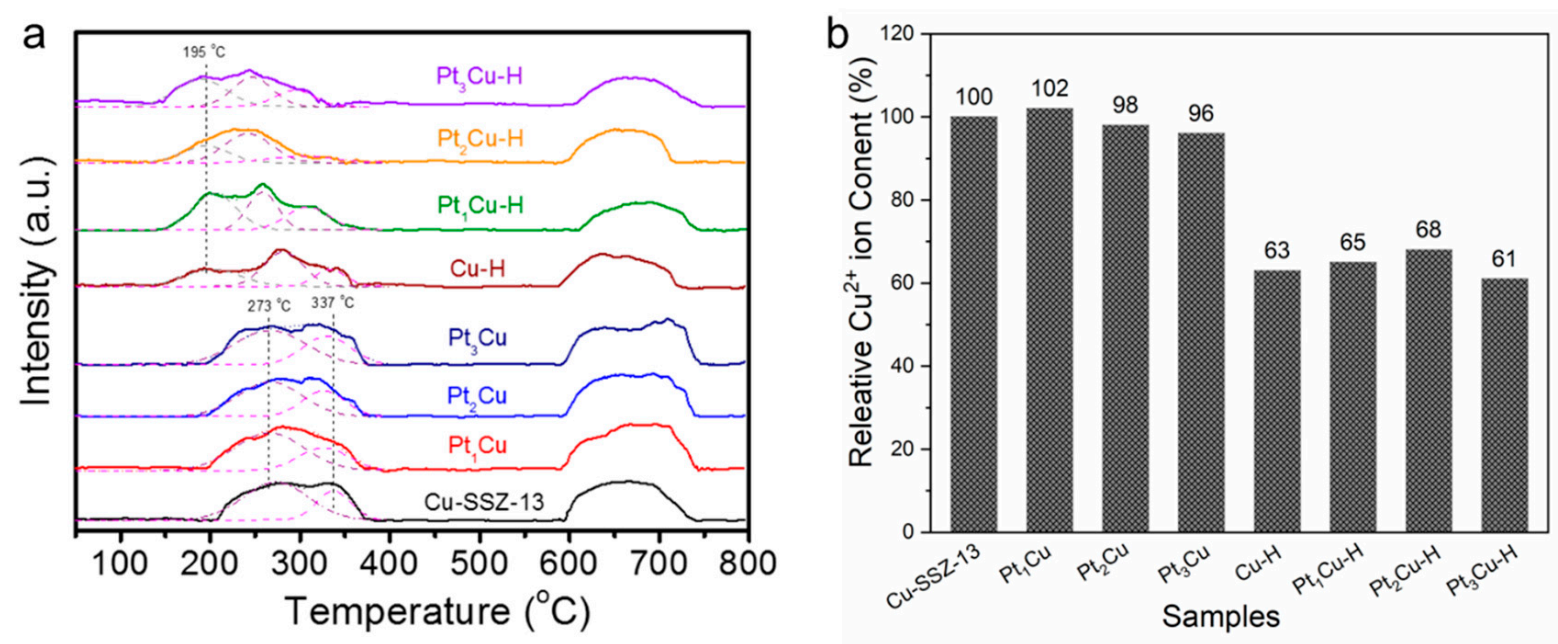

Figure 4. (a) $\mathrm{H}_{2}$-TPR spectra of fresh and aged Cu-SSZ-13 and PtxCu samples; (b) the relative $\mathrm{Cu}^{2+}$ ion content in the catalyst samples, using Cu-SSZ-13 as a reference.

After deconvolution, the peak in the $220-380^{\circ} \mathrm{C}$ range can be divided into two peaks with tops at $250{ }^{\circ} \mathrm{C}$ and $325^{\circ} \mathrm{C}$, assigned to the reduction of isolated $\mathrm{Cu}^{2+}$ located in eightand six-member rings, respectively [30]. After the hydrothermal treatment, the reduction peak below $500{ }^{\circ} \mathrm{C}$ was widened, and an additional peak at $190{ }^{\circ} \mathrm{C}$ appeared. This can be attributed to the transformation of a part of the isolated $\mathrm{Cu}^{2+}$ ions to $\mathrm{CuO}$ during the hydrothermal treatment [31]. 
The isolated $\mathrm{Cu}^{2+}$ ions content of each sample was normalized using the area of the reduction peaks of isolated $\mathrm{Cu}^{2+}$ ions in Cu-SSZ-13 as a reference, shown in Figure $4 \mathrm{~b}$. The $\mathrm{Cu}-\mathrm{SSZ}-13$ and PtxCu samples contained similar isolated $\mathrm{Cu}^{2+}$ ions contents. This suggests that the Pt poisoning has no influence on the cupric sites, which is consistent with previous work [6]. Therefore, the parallel reactions should exclusively be catalyzed by the Pt species, which reduced the SCR activities. Furthermore, the SCR active sites, i.e., isolated $\mathrm{Cu}^{2+}$ ions, decreased, and the Pt content remained constant (Figure $4 \mathrm{~b}$ ), while the SCR activity was increased for the $\mathrm{Pt}_{\mathrm{x}} \mathrm{Cu}$ samples after hydrothermal treatment. This indicates that the hydrothermal conditions might change the state of $\mathrm{Pt}$, which plays a critical role in determining the SCR's performance.

\subsubsection{X-ray Photoelectron Spectroscopy}

To detect the changes of state in Pt, the XPS technique was utilized, and the Pt $4 \mathrm{f}$ spectra of the fresh and aged samples are given in Figure 5a,b, respectively. The Cu-SSZ-13 sample displayed no Pt signals, and a broad peak at $70-80 \mathrm{eV}$ was observed in the PtxCu samples. The signals for the $\mathrm{Pt} 4 \mathrm{f}_{7 / 2}$ peaks with a binding energy value at $71.32 \mathrm{eV}$ confirmed the presence of platinum in the zero oxidation state $\left(\mathrm{Pt}^{0}\right)$ [32]. The $\mathrm{Pt} 4 \mathrm{f}_{7 / 2}$ signals at around 72.96 and 74.01 are attributed to $\mathrm{PtO}$ and $\mathrm{PtO}_{2}$ species, respectively, which were formed due to the $\mathrm{Pt}^{0}$ oxidation during the catalyst's calcination in preparation [33]. In comparison, only reduced Pt was observed in the previous work on Pt-poisoned Cu-SSZ-13 [6]. This might be attributed to the different Pt precursors used in the work by Lezcano-Gonzalez et al. $\left(\left[\mathrm{Pt}\left(\mathrm{NH}_{3}\right)_{4}\right]\left(\mathrm{NO}_{3}\right)_{2}\right)$ and in our work $\left(\mathrm{Pt}\left(\mathrm{NO}_{3}\right)_{2}\right)$, as the different precursors have an influence on the state of the Pt [6,34]. After the hydrothermal treatment, the XPS spectra of the hydrothermally aged samples changed. Only the $\mathrm{PtO}$ and $\mathrm{PtO}_{2}$ species remained in the aged samples. This indicates that all the $\mathrm{Pt}^{0}$ was oxidized during the aging process, which is consistent with the pervious works that reported that the $\mathrm{Pt}^{0}$ would be easily oxidized at high temperatures [16,18].

a

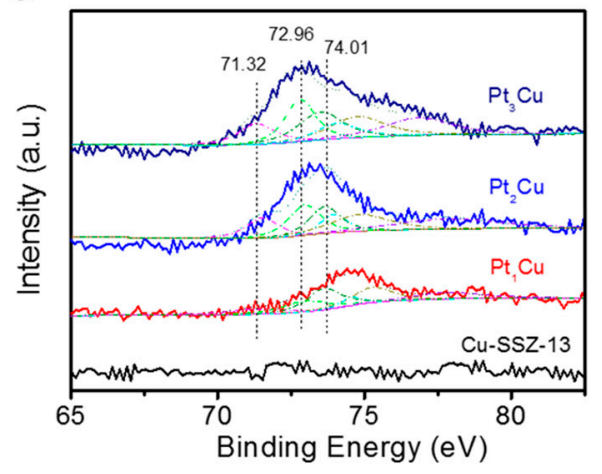

b

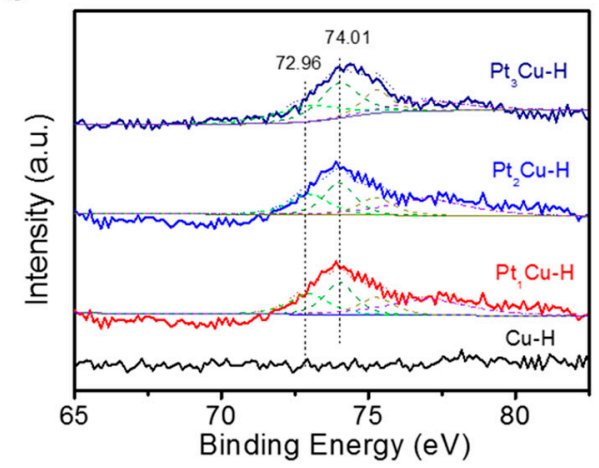

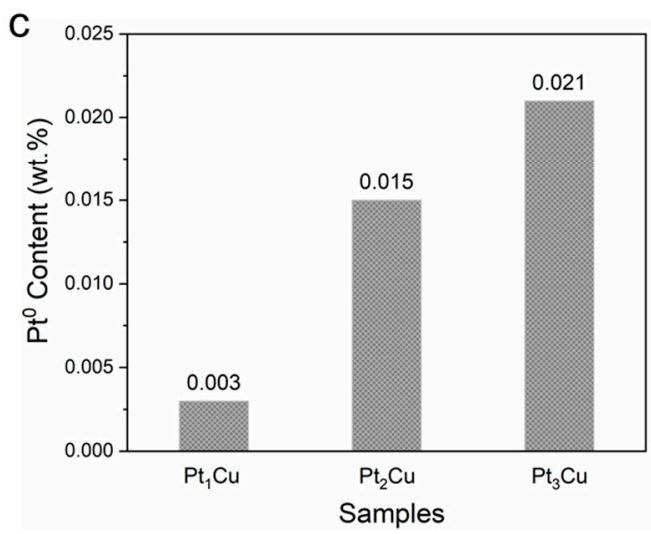

Figure 5. Pt $4 \mathrm{f} X \mathrm{PS}$ results of the catalyst samples. (a) Fresh samples, (b) aged samples, (c) $\mathrm{Pt}^{0}$ content in PtxCu samples. 
The $\mathrm{Pt}^{0}$ content of each sample was calculated, as shown in Figure $5 \mathrm{c}$ (details shown in Figure S3). The $\mathrm{Pt}^{0}$ content increased in the order of $\mathrm{Pt}_{3} \mathrm{Cu}>\mathrm{Pt}_{2} \mathrm{Cu}>\mathrm{Pt}_{1} \mathrm{Cu}>\mathrm{Cu}-$ SSZ-13, consistent with the extent of the deactivation of the Pt-loaded samples (Figure 1). Combined with the transient reaction results in Table 1, it is suggested that the $\mathrm{Pt}^{0}$ catalyzed the R.2-7, decreasing the deNO $\mathrm{O}_{\mathrm{x}}$ activities of the PtxCu samples (Figure 1). In addition, the aged Cu-SSZ-13 and PtxCu exhibited similar SCR activities after hydrothermal treatment, although a large content of $\mathrm{PtO}_{\mathrm{x}}$ still existed in the $\mathrm{PtxCu}-\mathrm{H}$ samples (Figures 1 and $5 b$ ). This demonstrates that the $\mathrm{PtO}_{\mathrm{x}}$ is ineffective in catalyzing the parallel reactions. In other words, the transformation of $\mathrm{Pt}^{0}$ into $\mathrm{PtO}_{\mathrm{x}}$ results in the regeneration of $\mathrm{PtxCu}$ samples after hydrothermal treatment.

\section{Experimental}

\subsection{Catalyst Preparation}

The Cu-SSZ-13 was synthesized via one-pot hydrothermal synthesis using coppertetraethylenepentamine (Cu-TEPA, Guangfu, Tanjin) as a structure-directing agent. In total, $180 \mathrm{~mL}$ of gel was prepared with a molar ratio of $2.5 \mathrm{Na}_{2} \mathrm{O}: 1 \mathrm{Al}_{2} \mathrm{O}_{3}: 10 \mathrm{SiO}_{2}: 150 \mathrm{H}_{2} \mathrm{O}: 2$ $\mathrm{Cu}$-TEPA, which was then transferred into a $250 \mathrm{~mL}$ autoclave with a Teflon liner and crystallized at $140^{\circ} \mathrm{C}$ for 4 days. The solid product was filtrated, washed with water, and then dried at $120^{\circ} \mathrm{C}$ for $6 \mathrm{~h}$. Then, $15 \mathrm{~g}$ of as-synthesized sample was ion-exchanged with $300 \mathrm{~mL} \mathrm{NH}_{4} \mathrm{NO}_{3}$ solution $(1 \mathrm{~mol} / \mathrm{L})$ at $80^{\circ} \mathrm{C}$ and kept for $9 \mathrm{~h}$ to remove excess $\mathrm{Cu}$. After filtration, washing, and drying at $100{ }^{\circ} \mathrm{C}$, the sample was calcinated in synthetic air at $600{ }^{\circ} \mathrm{C}$ for $6 \mathrm{~h}$ to obtain $\mathrm{Cu}-\mathrm{SSZ}-13$. The $\mathrm{Si} / \mathrm{Al}$ ratio of $\mathrm{Cu}-\mathrm{SSZ}-13$ is 4 , as determined by ICP-OES. The details of the preparation can be found in our previous work [14].

The Pt-doped Cu-SSZ-13 catalysts (Pt/Cu-SSZ-13 = 0.01, 0.05, $0.1 \mathrm{wt}$. \%) were prepared by incipient wetness impregnation. Typically, $0.6 \mathrm{~mL} \mathrm{Pt}\left(\mathrm{NO}_{3}\right)_{2}$ solution (Guangfu) at different concentrations ( $0.088,0.44$ and $0.88 \mathrm{~mol} / \mathrm{L}$, respectively) was dropped onto $1 \mathrm{~g}$ of $\mathrm{Cu}-\mathrm{SSZ}-13$. After calcination at $550{ }^{\circ} \mathrm{C}$ for $4 \mathrm{~h}$, the catalysts with different $\mathrm{Pt}$ loadings were obtained. The samples were denoted as $\mathrm{Pt}_{1} \mathrm{Cu}, \mathrm{Pt}_{2} \mathrm{Cu}$ and $\mathrm{Pt}_{3} \mathrm{Cu}$ for short, respectively.

All catalysts were treated at $750{ }^{\circ} \mathrm{C}$ in air with $10 \% \mathrm{H}_{2} \mathrm{O}$ for $12 \mathrm{~h}$. The flow rate was kept at $500 \mathrm{~mL} / \mathrm{min}$. The hydrothermally aged samples with Pt loading were distinguished with the suffix of $(-\mathrm{H})$, and $\mathrm{Cu}-\mathrm{H}$ was used as the abbreviation for the aged $\mathrm{Cu}-\mathrm{SSZ}-13$.

\subsection{Catalytic Performance Test}

The $\mathrm{NH}_{3}$-SCR activities of the catalysts were tested in a fixed-bed quartz reactor (10 mm in diameter). Typically, $100 \mathrm{mg}$ of the catalyst (40-60 mesh) was used, which was pre-activated in $5 \% \mathrm{O}_{2} / \mathrm{N}_{2}$ flow at $550{ }^{\circ} \mathrm{C}$ for $1 \mathrm{~h}$. The reactant gases contain $500 \mathrm{ppm} \mathrm{NO}$, $500 \mathrm{ppm} \mathrm{NH}{ }_{3}, 5$ vol. $\% \mathrm{O}_{2}$, and $\mathrm{N}_{2}$ as balance. The gas flow was kept at $500 \mathrm{~mL} / \mathrm{min}$, and the corresponding GHSV was $150,000 \mathrm{~h}^{-1}$. The concentrations of the products $\left(\mathrm{NO}, \mathrm{N}_{2} \mathrm{O}\right.$ and $\mathrm{NO}_{2}$ ) were recorded on an FTIR gases analyzer (Thermo Nicolet iS10, Madison, WI, USA) with a $2 \mathrm{~m}$ gas cell when the reaction reached a steady state (less than $1 \mathrm{ppm}$ change in ten minutes). The $\mathrm{NO}_{\mathrm{x}}\left(\mathrm{NO}_{\mathrm{x}}=\mathrm{NO}+\mathrm{NO}_{2}\right)$ conversion was calculated according to R.10:

$$
N O_{\mathrm{x}}=\left(1-\frac{\left[N O_{x}\right]_{\text {out }}}{\left[N O_{x}\right]_{\text {in }}}\right) \times 100 \%
$$

\subsection{Transient Reaction}

Transient reactions were carried out at 330 and $460{ }^{\circ} \mathrm{C}$. First, a similar reaction condition as in the standard SCR measurement mentioned above was adopted for the $\mathrm{NH}_{3}$ oxidation reaction, in which $\mathrm{NO}$ was not introduced into the gas mixture. After the reaction reached a steady state, $500 \mathrm{ppm} \mathrm{NO}$ was switched into the reaction system. The concentrations of the gases $\left(\mathrm{NO}, \mathrm{NO}_{2}, \mathrm{~N}_{2} \mathrm{O}\right.$ and $\mathrm{NH}_{3}$ ) were measured with the FTIR gas analyzer (Thermo Nicolet iS10).

The surface area and pore volume were determined by $\mathrm{N}_{2}$ physisorption measurement at $-196{ }^{\circ} \mathrm{C}$ using a Quantachrome Autosorb-1, with pre-degassing at $250^{\circ} \mathrm{C}$ for $6 \mathrm{~h}$. The 
chemical composition of the sample was determined by ICP-OES (VISTA-MPX, Varian, Palo Alto, CA, USA). The $\mathrm{H}_{2}$ temperature-programmed reduction $\left(\mathrm{H}_{2}-\mathrm{TPR}\right)$ was conducted on an AutoChem II 2920 (Micromeritics, Norcross, GA, USA) instrument. The samples were treated at $550{ }^{\circ} \mathrm{C}$ in $10 \% \mathrm{O}_{2} / \mathrm{N}_{2}$ for $1 \mathrm{~h}$ before testing. X-ray photoelectron spectroscopy (XPS) was performed with a PHI-1600 ESCA system spectrometer(Perkin- Elmer Co., USA) using $\mathrm{Mg} \mathrm{K} \alpha$ as the $\mathrm{X}$-ray source $(1253.6 \mathrm{eV})$ under a residual pressure of $5 \times 10^{-6} \mathrm{~Pa}$. The error of the binding energy was calibrated using $\mathrm{C} 1 \mathrm{~s}$ at $284.6 \mathrm{eV}$ as the standard.

\section{Conclusions}

The Cu-SSZ-13 suffered severe deactivation after Pt impregnation, resulting in a decrease in $\mathrm{NO}_{x}$ conversion. The $\mathrm{Pt}^{0}$ species accelerated the $\mathrm{NH}_{3}$ selective oxidation reaction to $\mathrm{N}_{2}$ in the temperature range below $330{ }^{\circ} \mathrm{C}$, reducing the deNO activity of $\mathrm{PtxCu}$ samples due to the insufficient amount of reductant taking part in the standard $\mathrm{NH}_{3}$-SCR reaction. In addition to the over-consumption of $\mathrm{NH}_{3}$ due to $\mathrm{NH}_{3}$ oxidation, the formation of $\mathrm{NO}$ and $\mathrm{NO}_{2}$ via $\mathrm{NH}_{3}$ and $\mathrm{NO}$ oxidation (R.3-R.7) further increased the loss of deNOx activity in Pt-poisoned samples at high temperatures (around $460{ }^{\circ} \mathrm{C}$ ). The NSCR (R.2) reaction contributed to the increased $\mathrm{N}_{2} \mathrm{O}$ formation in Pt-poisoned samples at around $330^{\circ} \mathrm{C}$. After hydrothermal treatment, the activity was mostly recovered due to the transformation of $\mathrm{Pt}^{0}$, which catalyzed the parallel reactions, into $\mathrm{PtO}_{\mathrm{x}}$ species.

Supplementary Materials: The following are available online at https:/ / www.mdpi.com/article / 10.3390 / catal11070796/s1, Figure S1: $\mathrm{NH}_{3}$ conversion as a function of temperature during $\mathrm{NH}_{3}$ oxidation experiment for the Cu-SSZ-13 and PtxCu samples. Reactant feed contains $500 \mathrm{ppm} \mathrm{NH}_{3}$, $5 \% \mathrm{O}_{2} 5 \% \mathrm{H}_{2} \mathrm{O}$, balanced with $\mathrm{N}_{2}$; flow rate at $500 \mathrm{~mL} / \mathrm{min}$, GHSV: 150,000 h${ }^{-1}$, Figure S2: $\mathrm{NO}_{2}$ formation as a function of temperature during $\mathrm{NH}_{3}$-SCR reaction. The reactant feed contains $500 \mathrm{ppm}$ $\mathrm{NH}_{3}, 5 \% \mathrm{O}_{2}, 5 \% \mathrm{H}_{2} \mathrm{O}$, balanced with $\mathrm{N}_{2}$; flow rate at $500 \mathrm{~mL} / \mathrm{min}$, GHSV: 150,000 $\mathrm{h}^{-1}$, Figure S3: XRD patterns of the (a) fresh and (b) aged catalysts, Figure S4: Solid state ${ }^{27}$ Al MAS NMR spectra of the Cu-SSZ-13 and Pt-poisoned samples, Figure S5: Ratio of different Pt species in the Pt loading samples quantified by the XPS spectra in Figure 5, Figure S6: TEM images of (a) $\mathrm{Pt}_{3} \mathrm{Cu}$ and (b) $\mathrm{Pt}_{3} \mathrm{Cu}-\mathrm{H}$ samples.

Author Contributions: H.Z.: literature search, figures, study design, data collection, writing; L.H.: literature search, figures, study design; Y.W.: figures, study design; J.Z.: data analysis. All authors have read and agreed to the published version of the manuscript.

Funding: This work was supported by the Scientific Research Funds of Huaqiao University (60550Y200270001).

Conflicts of Interest: The authors declare no conflict of interest.

\section{References}

1. Beale, A.M.; Gao, F.; Lezcano-Gonzalez, I.; Peden, C.H.F.; Szanyi, J. Recent advances in automotive catalysis for NOx emission control by small-pore microporous materials. Chem. Soc. Rev. 2015, 44, 7371-7405. [CrossRef]

2. Nova, I.; Tronconi, E. Urea-SCR Technology for deNOx after Treatment of Diesel Exhausts; Springer: New York, NY, USA, 2014.

3. Shen, M.; Zhang, Y.; Wang, J.; Wang, C.; Wang, J. Nature of SO3 poisoning on Cu/SAPO-34 SCR catalysts. Catalysts 2018, 358, 277-286. [CrossRef]

4. Kumar, A.; Smith, M.A.; Kamasamudram, K.; Currier, N.W.; An, H.; Yezerets, A. Identification of two types of Cu sites in $\mathrm{Cu} / \mathrm{SSZ}-13$ and their unique responses to hydrothermal aging and sulfur poisoning. Catal. Today 2014, 231, 75-82. [CrossRef]

5. Gao, F.; Szanyi, J. On the hydrothermal stability of Cu/SSZ-13 SCR catalysts. Appl. Catal. A Gen. 2018, 560, 185-194. [CrossRef]

6. Lezcano-Gonzalez, I.; Deka, U.; van der Bij, H.E.; Paalanen, P.; Arstad, B.; Weckhuysen, B.M.; Beale, A.M. Chemical deactivation of Cu-SSZ-13 ammonia selective catalytic reduction ( $\left.\mathrm{NH}_{3}-\mathrm{SCR}\right)$ systems. Appl. Catal. B Environ. 2014, 339-349, 154-155. [CrossRef]

7. Hammershøi, P.S.; Jangjou, Y.; Epling, W.S.; Jensen, A.D.; Janssens, T.V.W. Reversible and irreversible deactivation of Cu-CHA $\mathrm{NH}_{3}$-SCR catalysts by $\mathrm{SO}_{2}$ and $\mathrm{SO}_{3}$. Appl. Catal. B Environ. 2018, 226, 38-45. [CrossRef]

8. Wang, C.; Wang, J.; Wang, J.; Yu, T.; Shen, M.; Wang, W.; Li, W. The effect of sulfate species on the activity of $\mathrm{NH}_{3}-\mathrm{SCR}$ over Cu/SAPO-34. Appl. Catal. B Environ. 2017, 204, 239-249. [CrossRef]

9. Kim, Y.J.; Lee, J.K.; Min, K.M.; Hong, S.B.; Nam, I.-S.; Cho, B.K. Hydrothermal stability of CuSSZ13 for reducing NOx by NH 3 . J. Catal. 2014, 311, 447-457. [CrossRef] 
10. Ma, J.; Si, Z.C.; Weng, D.; Wu, X.D.; Ma, Y. Potassium poisoning on Cu-SAPO-34 catalyst for selective catalytic reduction of NOx with ammonia. Chem. Eng. J. 2015, 267, 191-200. [CrossRef]

11. Fan, C.; Chen, Z.; Pang, L.; Ming, S.; Dong, C.; Albert, K.B.; Liu, P.; Wang, J.; Zhu, D.; Chen, H.; et al. Steam and alkali resistant $\mathrm{Cu}-\mathrm{SSZ}-13$ catalyst for the selective catalytic reduction of NOx in diesel exhaust. Chem. Eng. J. 2018, 334, 344-354. [CrossRef]

12. Shwan, S.; Jansson, J.; Olsson, L.; Skoglundh, M. Chemical deactivation of Fe-BEA as $\mathrm{NH}_{3}$-SCR catalyst-Effect of phosphorous. Appl. Catal. B Environ. 2014, 147, 111-123. [CrossRef]

13. Wang, J.; Zhao, H.; Haller, G.; Li, Y. Recent advances in the selective catalytic reduction of NOx with NH3 on Cu-Chabazite catalysts. Appl. Catal. B Environ. 2017, 202, 346-354. [CrossRef]

14. Zhao, H.; Zhao, Y.; Liu, M.; Li, X.; Ma, Y.; Yong, X.; Chen, H.; Li, Y. Phosphorus modification to improve the hydrothermal stability of a Cu-SSZ-13 catalyst for selective reduction of NOx with NH3. Appl. Catal. B Environ. 2019, 252, 230-239. [CrossRef]

15. Gu, Y.; Marino, S.; Cortés-Reyes, M.; Pieta, I.S.; Pihl, J.A.; Epling, W.S. Integration of an Oxidation Catalyst with Pd/Zeolite-Based Passive NOx Adsorbers: Impacts on Degradation Resistance and Desorption Characteristics. Ind. Eng. Chem. Res. 2020, 60, 6455-6464. [CrossRef]

16. Chen, X.; Currier, N.; Yezerets, A.; Kamasamudram, K. Axially Resolved Performance of Cu-Zeolite SCR Catalysts. SAE Int. J. Engines 2013, 6, 856-861. [CrossRef]

17. Girard, J.W.; Montreuil, C.; Kim, J.; Cavataio, G.; Lambert, C. Origin and Effect of Ultra-Low Platinum Contamination on Diesel-SCR Catalysts. SAE Int. J. Fuels Lubr. 2008, 1, 1553-1559.

18. Yu, T.; Xu, M.; Huang, Y.; Wang, J.; Wang, J.; Lv, L.; Qi, G.; Li, W.; Shen, M. Insight of platinum poisoning Cu/SAPO-34 during $\mathrm{NH}_{3}$-SCR and its promotion on catalysts regeneration after hydrothermal treatment. Appl. Catal. B Environ. 2017, 204, 525-536. [CrossRef]

19. Cavataio, G.; Jen, H.-W.; Girard, J.W.; Dobson, D.; Warner, J.R.; Lambert, C.K. Laboratory Study of Soot, Propylene, and Diesel Fuel Impact on Zeolite-Based SCR Filter Catalysts. SAE Int. J. Fuels Lubr. 2009, 2, 204-216. [CrossRef]

20. Lezcano-Gonzalez, I.; Wragg, D.S.; Slawinski, W.A.; Hemelsoet, K.; Deyne, A.; Waroquier, M.; van Speybroeck, V.; Beale, A.M. Determination of the Nature of the $\mathrm{Cu}$ Coordination Complexes Formed in the Presence of $\mathrm{NO}$ and $\mathrm{NH}_{3}$ within SSZ-13. J. Phys. Chem. C 2015, 119, 24393-24403. [CrossRef]

21. Wang, J.; Cui, H.; Dong, X.; Zhao, H.; Wang, Y.; Chen, H.; Yao, M.; Li, Y. $\mathrm{N}_{2} \mathrm{O}$ formation in the selective catalytic reduction of NOx with NH3ona CeMoOx catalyst. Appl. Catal. A Gen. 2015, 505, 8-15. [CrossRef]

22. Dong, X.; Wang, J.; Zhao, H.; Li, Y. The promotion effect of CeOx on Cu-SAPO-34 catalyst for selective catalytic reduction of NOx with ammonia. Catal. Today 2015, 258, 28-34. [CrossRef]

23. Zhao, H.; Li, H.; Li, X.; Liu, M.; Li, Y. The promotion effect of Fe to Cu-SAPO-34 for selective catalytic reduction of NOx with $\mathrm{NH}_{3}$. Catal. Today 2017, 297, 84-91. [CrossRef]

24. Zhao, H.; Zhao, Y.; Ma, Y.; Yong, X.; Wei, M.; Chen, H.; Zhang, C.; Li, Y. Enhanced hydrothermal stability of a Cu-SSZ-13 catalyst for the selective reduction of NOx by NH3 synthesized with SAPO-34 micro-crystallite as seed. J. Catal. 2019, 377, 218-223. [CrossRef]

25. Shan, Y.; Shi, X.; Yan, Z.; Liu, J.; Yu, Y.; He, H. Deactivation of Cu-SSZ-13 in the presence of $\mathrm{SO}_{2}$ during hydrothermal aging. Catal. Today 2019, 320, 84-90. [CrossRef]

26. Shan, Y.; Du, J.; Yu, Y.; Shan, W.; Shi, X.; He, H. Precise control of post-treatment significantly increases hydrothermal stability of in-situ synthesized cu-zeolites for NH3-SCR reaction. Appl. Catal. B Environ. 2020, 266, 118655. [CrossRef]

27. Shan, Y.; Sun, Y.; Du, J.; Zhang, Y.; Shi, X.; Yu, Y.; Shan, W.; He, H.H. Hydrothermal aging alleviates the inhibition effects of NO2 on Cu-SSZ-13 for NH3-SCR. Appl. Catal. B Environ. 2020, 275, 119105. [CrossRef]

28. Gao, F.; Walter, E.D.; Karp, E.M.; Luo, J.; Tonkyn, R.G.; Kwak, J.H.; Szanyi, J.; Peden, C.H.F. Structure-activity relationships in NH3-SCR over Cu-SSZ-13 as probed by reaction kinetics and EPR studies. J. Catal. 2013, 300, 20-29. [CrossRef]

29. Kwak, J.H.; Tonkyn, R.G.; Kim, D.H.; Szanyi, J.; Peden, C.H.F. Excellent activity and selectivity of Cu-SSZ-13 in the selective catalytic reduction of NOx with NH3. J. Catal. 2010, 275, 187-190. [CrossRef]

30. Kwak, J.H.; Zhu, H.; Lee, J.H.; Peden, C.H.F.; Szanyi, J. Two different cationic positions in Cu-SSZ-13? Chem. Commun. 2012, 48, 4758-4760. [CrossRef]

31. Li, X.; Zhao, Y.; Zhao, H.; Liu, M.; Ma, Y.; Yong, X.; Chen, H.; Li, Y. The Cu migration of Cu-SAPO-34 catalyst for ammonia selective catalytic reduction of NOx during high temperature hydrothermal aging treatment. Catal. Today 2019, 237, 126-133. [CrossRef]

32. Cordatos, H.; Gorte, R.J. CO, NO, and $\mathrm{H}_{2}$ Adsorption on Ceria-Supported Pd. J. Catal. 1996, 159, 112-118. [CrossRef]

33. Şen, F.; Gökağaç, G.; Şen, S. High performance Pt nanoparticles prepared by new surfactants for C1 to C3 alcohol oxidation reactions. J. Nanopart. Res. 2013, 15, 1979. [CrossRef]

34. Borges, L.R.; Lopez-Castillo, A.; Meira, D.M.; Gallo, J.M.R.; Zanchet, D.; Bueno, J.M.C. Effect of the Pt Precursor and Loading on the Structural Parameters and Catalytic Properties of $\mathrm{Pt} / \mathrm{Al}_{2} \mathrm{O}_{3}$. ChemCatChem 2019, 11, 3064-3074. [CrossRef] 